\title{
ELEOCHARIS REZNICEKII (CYPERACEAE), A NEW SPECIES FROM THE MEXICAN HIGH PLATEAU
}

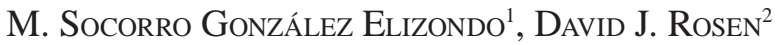 \\ Richard Carter ${ }^{3}$ and Paul M. Peterson ${ }^{4}$ \\ ${ }^{1}$ Instituto Politécnico Nacional, Centro Interdisciplinario de Investigación \\ para el Desarrollo Integral Regional, Unidad Durango. Sigma s.n. \\ Fraccionamiento 20 de Noviembre II, 34220 Durango, Durango, México. \\ herbario_ciidir@yahoo.com.mx \\ ${ }^{2}$ Texas A\&M University, College Station, \\ Department of Ecosystem Science \& Management, \\ S.M. Tracy Herbarium Texas 77843-2126, U.S.A. \\ ${ }^{3}$ Valdosta State University, Department of Biology, Herbarium, \\ Valdosta, Georgia 31698-0015, U.S.A. \\ ${ }^{4}$ National Museum of Natural History, Smithsonian Institution, \\ Department of Botany, \\ Washington, DC, 20013-7012, U.S.A.
}

\begin{abstract}
Eleocharis reznicekii (Cyperaceae, subg. Eleocharis, series Eleocharis), is described and illustrated. It is morphologically intermediate between E. densa and two species of Eleocharis subseries Eleocharis (E. macrostachya and E. palustris). The new species differs in a combination of characters including conspicuously compressed culms ( 3 to over 5 times wider than thick) and stylopodium sessile on a thin annular base. Eleocharis reznicekii differs additionally from $E$. densa by having relatively lax spikelets, mostly bifid styles, and achenes almost smooth at 30x. From E. macrostachya and E. palustris it is distinguished in its oblong to linear-oblong spikelets, the proximal floral scale clasping only $1 / 3$ to slightly more than $1 / 2$ of the culm, and the proximal plus 1-2(3) subproximal scales without a flower. Eleocharis reznicekii is known only from the state of Durango, in the Mexican high plateau and piedmont of the Sierra Madre Occidental.
\end{abstract}

Key words: Cyperaceae, Durango, Eleocharis, Mexico, taxonomy. 


\section{RESUMEN}

Se describe e ilustra Eleocharis reznicekii (Cyperaceae, subg. Eleocharis, serie Eleocharis), especie con características morfológicas intermedias entre las de Eleocharis densa y las de dos especies de la subserie Eleocharis (E. macrostachya y E. palustris). Se distingue por tener tallos conspicuamente comprimidos (3-5 veces más anchos que gruesos en fresco) y estilopodio sésil sobre una base anular fina. De E. densa se distingue además por tener espiguillas menos densas, estilos en su mayoría bífidos y aquenio casi liso a 30x, más redondeado hacia el ápice. De E. macrostachya y E. palustris lo hace por su hábito más robusto, espiguillas oblongas a linear-oblongas, gluma proximal envolviendo únicamente $1 / 3$ a poco más de $1 / 2$ de la base de la espiga, y por tener la gluma proximal y 1 a $2(3)$ glumas subproximales sin flor. Hasta ahora, E. reznicekii se conoce solamente del estado de Durango, en el Altiplano Mexicano y piedemonte de la Sierra Madre Occidental.

Palabras clave: Cyperaceae, Durango, Eleocharis, México, taxonomía.

A field trip in the Mexican state of Durango organized after the symposia The Role of Botany in the Management and Conservation of Ecosystems and the 2nd. Botanical Symposium of Northern Mexico led to the discovery of a conspicuous new species of Eleocharis R. Br.:

Eleocharis reznicekii S. González, D.J. Rosen, R. Carter \& P.M. Peterson, sp. nov. (Fig. 1). Type: Mexico. Estado Durango, mpio. Durango, W of roadside of MEX Hwy. 23, between Mezquital and Durango, ca. $26 \mathrm{~km} \mathrm{~S}$ of Durango, 16 Sep 2005, D.J. Rosen 3505, R. Guaglianone, A. Torres, S. González, R. Carter, P.M. Peterson (holotype: CIIDIR; isotypes: IEB, K, MEXU, MICH, NY, TAES, TEX, US, VSC, WIS).

Ad Eleocharitem densam, E. macrostachyam et E. palustrem valde accedit sed a prima differt spiculis laxifloris, stigmatibus plerumque 2 rarius 3 et achaenio fere laeviore; a secunda et tertia differt spiculis oblongis vel lineari-oblongis, squama infima $1 / 3$ ad aliquot plus quam $1 / 2$ spiculae basin amplectenti, squamis inferioribus 2 vel 4 vacuis; et ab omnibus culmis ultra complanatis leviter tortilibus et stylopodiis sessilibus in basi annulari insidentibus differt.

Plants perennial, mat-forming, roots coarse, fibrous, pale brown; rhizomes 3.5-4.5 mm thick, horizontal, conspicuous, firm, cortex persistent, hard, longer internodes to $5.3 \mathrm{~cm}$ long, scaly, scales to $16 \mathrm{~mm}$ long, persistent, membranous, pale 


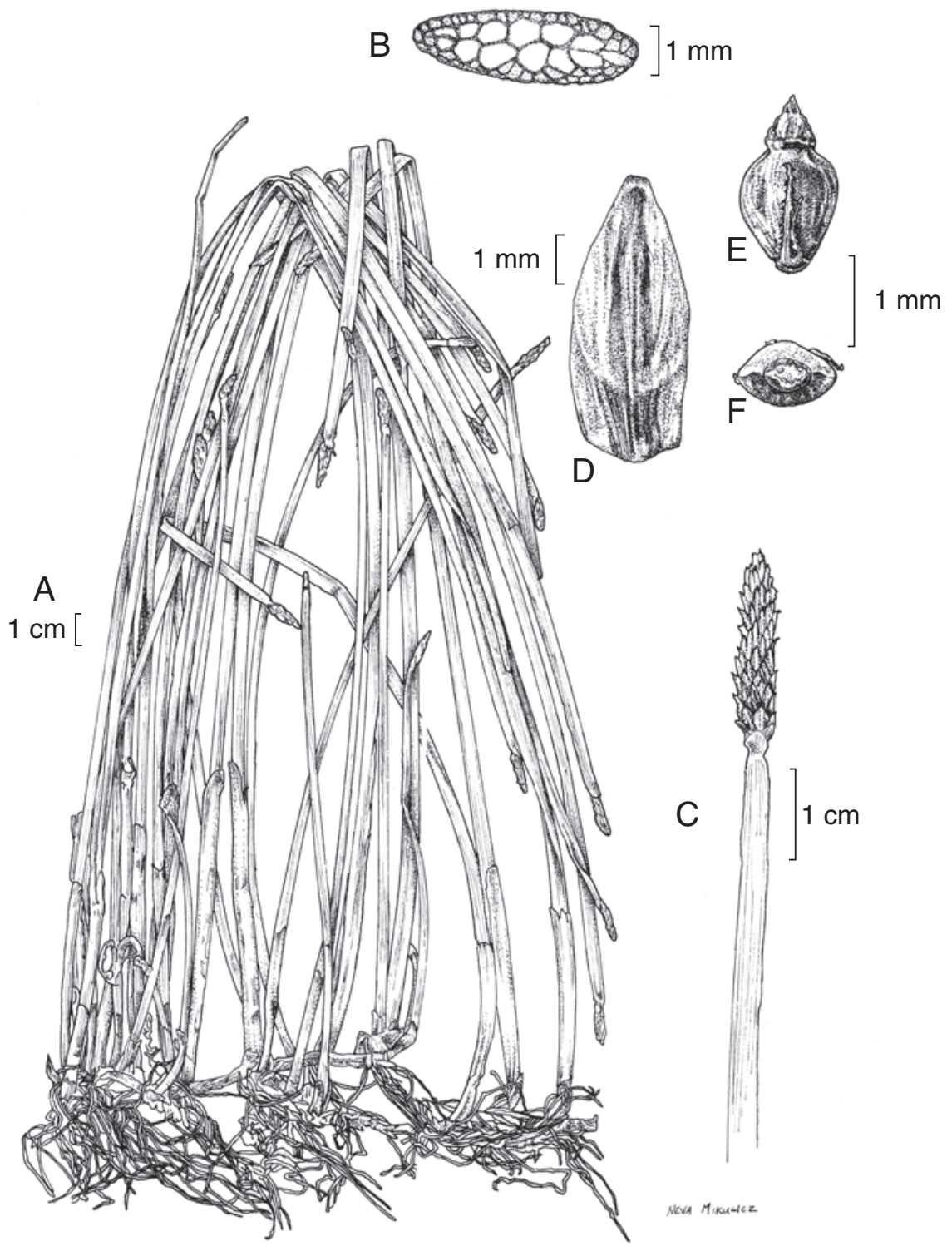

Fig. 1. Eleocharis reznicekii S. González, D.J. Rosen, R. Carter \& P.M. Peterson, from the type. A. habit; B. transverse section of culm below spikelet; C. spikelet; D. floral scale (abaxial view); E. achene (abaxial view); F. achene (apical view). 
chestnut when young, dark grayish brown with age. Fertile culms (30-)50-68 cm tall x 2.6-6 mm wide, markedly compressed distally, broadly ovoid in cross section to ribbon-like, compressed to sub-terete proximally, weakly to conspicuously twisted, 3 to over 5 times wider than thick, pressed flat, longitudinally striate when dry with numerous blunt ridges, soft, internally spongy, bright green. Leaves 2, reduced to tubular sheaths; upper leaf sheath up to $15 \mathrm{~cm}$ long, membranous-translucent, loose but not inflated, friable, often splitting adaxially, stramineous to pale grayish brown, apex obtuse to subacute, not callose, tooth-like projection (mucro) absent or very short; lower leaf sheath much shorter than upper, membranous, dark grayish brown to almost black. Spikelets (16-)18-34 mm long x 3-3.7(-4) mm wide, oblong to linear-oblong or but slightly enlarged at base, acute or obtuse; proximal scale 2.1-3.1 mm long, without a flower, clasping $1 / 3$ to slightly more than $1 / 2$ of the culm, slightly constricted basally, of the same color and texture as the culm, apex rounded, the distal, hyaline membranous portion <0.1-0.3 mm long; subproximal 1-2(-3) scales of similar texture and length but narrower and with more evident hyaline apex, without a flower; floral scales (4.1-)4.3-4.7(-4.8) $\mathrm{mm}$ long x 1.5-1.9(-2) mm wide, lanceolate, deciduous, often spreading, stramineous or reddish-brown on the midrib region, midrib reddish, stramineous or green. Flowers with perianth of 1-5 slender bristles (sometimes 1 or 2 reduced or rudimentary), shorter than the achene or rarely overtopping the summit, retrorsely spinulose nearly to the base, colorless to pinkish or reddish-brown; stamens 3; anthers (1.4-)2-3.2 mm long, yellow to orangebrown; styles bifid (rarely some trifid in some spikelets). Achene body 1.2-1.5 mm long x 0.9-1.1 mm wide, biconvex, obovate or obpyriform, angles obscure, rounded at summit or with a short constriction about 0.3-0.4 times the width of the achene, smooth at $30 \mathrm{x}$, yellow, maturing to yellow-brown or brown. Stylopodium (0.3-)0.4$0.6 \mathrm{~mm}$ long $\mathrm{x}$ (0.3-)0.4-0.5 mm wide, conical to broadly lanceolate, light green to brownish, sessile on a thin, green or brownish annular base which is part of the achene summit.

Eleocharis reznicekii has some morphological features that are intermediate between E. densa Benth. and two species of the subseries Eleocharis: E. macrostachya Britton and E. palustris (L.) Roem. \& Schult. From the three species E. reznicekii differs in a combination of characters including conspicuously compressed culms ( 3 to over 5 times wider than thick) and stylopodium sessile on a thin annular base which is part of the achenium summit. From E. densa, E. reznicekii additionally differs by having relatively lax spikelets, mostly bifid styles, and almost smooth achenes at 30x. Eleocharis densa is usually represented in herbaria by specimens 
with very flattened culms, but it has terete culms when fresh; plants of $E$. densa with flattened culms mentioned by McVaugh (1993) could represent specimens of E. reznicekii. From E. macrostachya and E. palustris (as defined by Smith, 2002) it is distinguished by having oblong to linear-oblong spikelets, proximal floral scale clasping only $1 / 3$ to slightly more than $1 / 2$ of the culm, and 1 or 2(3) empty (without a flower) subproximal scales.

Ecology and Distribution. Eleocharis reznicekii grows in almost pure stands or mixed with Sagittaria, Nymphaea, and other species of Eleocharis (e.g., Eleocharis densa, E. macrostachya, E. ignota, and Eleocharis sp.) in standing water in deep soils that are sometimes slightly saline, between 1800 and $2530 \mathrm{~m}$ above sea level. Known from the Mexican plateau region and adjacent piedmont of the eastern slopes of the Sierra Madre Occidental; thus far E. reznicekii is known only from the state of Durango, but it may also exist in Zacatecas. A survey of many sites with suitable habitat during September 2006 yielded the discovery of only one additional locality, which indicates E. reznicekii is infrequent, although locally dominant. Two of the five populations known are infected by a sooty mold that gives a dark appearance to the spikelets.

Etymology. The name of the species is dedicated to our colleague and friend Dr. Anton Albert Reznicek, a tireless, sharp-eyed field botanist and specialist in several genera of sedges, who is the Curator of Vascular Plants at the University of Michigan Herbarium.

Additional specimens examined. México: Durango, $9 \mathrm{mi}$ NE of Durango, Route 31, 25 Jul 1958, D.S. Correll \& M.C. Johnston 20154 (LL); Durango, Granja Don Luis (cercanías), al NW del aeropuerto Guadalupe Victoria y al NE de la Cd. de Durango, por camino vecinal paralelo a las vías del FFCC, $24^{\circ} 08^{\prime} 15 " \mathrm{~N}$, $104^{\circ} 32$ '23" W, $1870 \mathrm{~m}$, humedal en suelo ligeramente salino, abundante en colonias, con Eleocharis, Nymphaea, Sagittaria y gramíneas, 20 Sep 2006, M.S. González 7208, M. Pinedo, F. Sánchez (ANSM, CHAP, CHAPA, CIIDIR, ENCB, ENEPI, HUAA, IBUG, IEB, MEXU, MO, NY, SI, UAMIZ, US); Durango, al S-SE, por la carretera a El Mezquital, entrada a rancho El Coro, 235'ㄴ' $4^{\prime \prime}$ N, 104³0'03" W, 1800 $\mathrm{m}$, en zona inundada, abundante, en colonia densa; tallos planos 3-4 mm de ancho, 16 Sep 2005, M.S. González 7105, R. Guaglianone, A. Torres, D. Rosen, R. Carter, P.M. Peterson (CIIDIR, IEB, MEXU, MICH); Súchil, Reserva de la Biosfera La Michilía, Mesa Larga, a orilla de Chapalita, 5 Sep 1992, 23²3' N, 104¹5' W, 
2530 m, A. García 1473 (CIIDIR); Súchil, Reserva de la Biosfera La Michilía, San Juan de Michis, $2 \mathrm{~km}$ al S por el camino a El Alemán, orilla de laguna La Virgen, 23²4'58" N, 1048'16" W, 4 Aug 2000, S. González 6254, S. Acevedo, A. López (ANSM, CIIDIR, ENCB, IBUG, IEB, MEXU, MICH, UAMIZ, US).

In the region where E. reznicekii occurs, Eleocharis densa grows in patches near populations of E. macrostachya and E. palustris. The intermediate morphological characteristics of E. reznicekii and the sympatric occurrence of its putative parents may indicate that this species is of hybrid origin. Hybridization rates are highest in small or peripheral populations (Rieseberg, 1997); Eleocharis densa reaches its northern limits of distribution in Durango. However, the fact that E. reznicekii is also sympatric with its putative parents makes difficult to accept the hybrid origin hypothesis unless a reproductive isolation mechanism exists. This hypothesis could be tested by a molecular phylogenetic study and/or cytogenetical analysis of this group.

Because of the perennial mat-forming habit, long, horizontal rhizomes with long internodes; mostly bifid styles; and biconvex, blunt angled, yellow to brown achenes almost smooth at 30x, E. reznicekii could be placed in Eleocharis subg. Eleocharis, sect. Eleocharis, ser. Eleocharis, subser. Eleocharis (González Elizondo \& Peterson 1997; Smith 2002), which is equivalent to series Palustriformes and subseries Palustres (invalid names: Svenson 1929, 1932, 1939, 1947, 1957). This group includes the "Eleocharis palustris complex", an extremely difficult group according to Svenson (1939), Smith (2001, 2002), and Strandhede (1966). Smith (2001, 2002) recognized seven species in the "Eleocharis palustris complex" for North America north of Mexico and discussed four variants of E. palustris.

Variation in response to different environmental conditions apparently has led to highly plastic character states making species limits difficult to interpret among members of this complex worldwide. For this reason we have been extremely cautious when considering the taxonomic status of E. reznicekii. Field and herbarium observations confirm the distinctive characteristics of this species. During a survey to locate more populations of E. reznicekii we found that in the wet season it grows only as an emergent in deep water, and we did not find any plants referable to $E$. reznicekii that have less compressed or more rigid culms out of the water. We also observed that other species of Eleocharis (e.g., E. palustris, E. densa, E. ignota S. González \& Reznicek, E. montevidensis Kunth, and E. parishii Britton) growing in aquatic or subaquatic habitats in the same region have cylindrical or polygonal culms, with the exception of E. macrostachya Britton, which also has compressed 
culms but differs in several other characters as indicated in the key. A variant of E. macrostachya with compressed culms has been called E. xyridiformis Fern. \& Brack., which additionally differs from typical E. macrostachya by having firmer culms, distal leaf sheath apices usually with a tooth to $0.6(-1) \mathrm{mm}$ long on some or all culms, and narrowly lanceoloid spikelets. This variant almost certainly deserves taxonomic recognition, perhaps as a species (Smith, 2002).

Because of the general habit, spikelet shape, proximal scale clasping $1 / 3$ to slightly more than $1 / 2$ of culm and being of the same color and texture as the culm, subproximal 1 or 2(3) scales of similar texture, lacking a flower, and size of the achenes, E. reznicekii resembles E. densa, a species related to E. elegans (Kunth) Roem. \& Schult., that has been considered as an intermediate between Eleocharis subseries Truncatae and subseries Eleocharis (González \& Peterson, 1997: 439). From the subseries Truncatae, E. densa differs by having the eventual presence of biconvex achenes, 2 or 3-branched styles, and membranous-translucent to thinly papery distal sheaths that are loose and sometimes disintegrate at the apex. Eleocharis densa is restricted to Megamexico 2, the biogeographical area comprising Mexico and northern Central America sensu Rzedowski (1991).

Eleocharis reznicekii has a robust habit and sheaths similar to E. densa and E. elegans, but its nearly smooth achenes and mostly bifid styles resemble those of species of subseries Eleocharis. The need to revise the supraspecific classification in section Eleocharis has also been pointed out by Roalson \& Friar (2000). In Mexico, both subseries, Eleocharis and Truncatae, are in need of a revision. A key to the Mexican species of Eleocharis subseries Eleocharis and to the robust, aquatic species of Truncatae is presented below:

1. Styles trifid or some bifid in the same spikelet; achenes plano-convex, slightly trigonous or biconvex, minutely reticulate ........................... 2

2. Culms without complete transverse septa; stylopodium lanceolate

E. densa

2. Culms with complete transverse septa (sometimes only evident by dissection of the culm in E. montana); stylopodium conic, deltoid to lanceolate ............. 3

3. Culms (0.7-)1-2.5(-3.1) mm wide; septa separated less than 6(-10) mm; stylopodium $0.2-0.35 \mathrm{~mm}$ long, conic to deltoid, mostly depressed ....... E. montana

3. Culms (1.2-)3-10 mm wide; septa separated more than (7-)10 mm; stylopodium (0.3-)0.4-0.7 mm long, lanceolate ................ E. elegans 
1. Styles bifid (rarely a few trifid in the same spikelet); achenes biconvex, smooth (at 30x) to finely rugulose ............................................. 4

4. Culms 2.6-6 mm wide, strongly compressed (3 to over 5 times wider than thick); proximal floral scale clasping $1 / 3$ to slightly more than $1 / 2$ of the culm; achenes smooth at 30x; stylopodium conic to broadly lanceolate, sessile on a thin disc which is part of the summit of the achene

E. reznicekii

4. Culms 0.7-3(-5) mm wide, terete to compressed (to 3 times wider than thick); proximal floral scale clasping $2 / 3$ to more than $3 / 4$ of the culm; achenes smooth or finely rugulose; stylopodium conic to deltoid, constricted at the base, not sessile on a thin disc 5

5. Proximal floral scale clasping $2 / 3(-3 / 4)$ of the culm, subproximal scale without a flower; apex of upper sheath obtuse to acute, without a mucro E. palustris

5. Proximal floral scale clasping $3 / 4$ or more of the culm, subproximal scale without or with a flower; apex of upper sheath obtuse to subtruncate, with or without a mucro ............................... E. macrostachya

\section{ACKNOWLEDGEMENTS}

We gratefully acknowledge Abraham Torres Soto, Martha González Elizondo, Marcos Pinedo Reyes, and Francisco Sánchez Alvarado for their help and companionship in the field. E. Rosa Guaglianone participated in the field trip where the new species was collected; she gracefully declined to coauthor this paper but joins us in honoring Dr. Reznicek. Dr. Galen Smith, Dr. Jerzy Rzedowski, and two anonymous reviewers made suggestions that greatly improved the manuscript. Research support for S. González was provided by COFAA and EDI of the Instituto Politécnico Nacional. Support for travel for D. Rosen was provided by the Frank W. Gould Award for Graduate Student Research in Plant Systematics and the Dr. Harry Wayne Springfield Graduate Student Endowment. Travel and research support for R. Carter was provided by the Faculty Development Fund, the Faculty International Activity Fund, and the Foundation of Valdosta State University. Travel for P.M. Peterson was provided by the Smithsonian Institution's Restricted Endowment Fund. Neva Mikulicz prepared the excellent illustration. We are also grateful to the staff of TEX/LL for loan of specimens for study that led to the discovery of an additional population of Eleocharis reznicekii. 


\section{LITERATURE CITED}

González-Elizondo, M. S. \& P. M. Peterson. 1997. A classification of and key to the supraspecific taxa in Eleocharis (Cyperaceae). Taxon 46: 433-449.

McVaugh, R. 1993. Cyperaceae. Flora Novo-Galiciana 13: 225-440.

Rieseberg, L. H. 1997. Hybrid origins of plant species. Annu. Rev. Ecol. Syst. 28: 359-389.

Roalson, E. H. \& E. A. Friar. 2000. Infrageneric classification of Eleocharis (Cyperaceae) revisited: Evidence from the internal transcribed spacer (ITS) region of nuclear ribosomal DNA. Syst. Bot. 25: 323-336.

Rzedowski, J. 1991. El endemismo en la flora fanerogámica mexicana: una apreciación analítica preliminar. Acta Bot. Mex. 15: 47-64.

Smith, S. G. 2001. Taxonomic innovations in North American Eleocharis (Cyperaceae). Novon 11: 241-257.

Smith, S. G. 2002. Eleocharis subg. Eleocharis sect. Eleocharis ser. Eleocharis. Flora of North America North of Mexico 23: 71-89.

Strandhede, S. O. 1966. Morphologic variation and taxonomy in Eleocharis subser. Palustres. Opera Bot. 10(2): 1-183.

Svenson, H. K. 1929. Monographic studies in the genus Eleocharis. Rhodora 31: 121-135, 152-163, 167-191, 199-219, 224-242.

Svenson, H. K. 1932. Monographic studies in the genus Eleocharis. Rhodora 34: 193-203, 215-227.

Svenson, H. K. 1939. Monographic studies in the genus Eleocharis V. Series 6: Palustriformes, subseries Palustres. Rhodora 41: 55-73.

Svenson, H. K. 1947. The group of Eleocharis palustris in North America. Rhodora 49: 6167.

Svenson, H. K. 1957. Eleocharis (Cyperaceae). North American Flora 18: 509-540 